\title{
Increased Activation and Differentiated Localization of Native and Phosphorylated STAT3 in Nasal Polyps
}

\author{
Robert Linke $^{a}$ Ralph Pries ${ }^{a}$ Michael Könnecke ${ }^{a}$ Karl Ludwig Bruchhage ${ }^{a}$ \\ Robert Böscke $^{a}$ Maximilian Gebhard $^{b}$ Barbara Wollenberg ${ }^{a}$

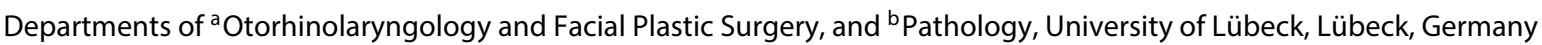

\author{
Key Words \\ Chronic rhinosinusitis - JAK-STAT pathway · Nasal polyp · \\ Phosphokinase · STAT3
}

\begin{abstract}
Background: Chronic rhinosinusitis with nasal polyps (CRSwNP) is a multifactorial disease; the underlying mechanisms of cell signalling are not fully understood. STAT3 (signal transducer and activator of transcription 3 ) is a phosphokinase and a key signalling molecule implicated in cell cycle regulation. We studied the distribution and expression of STAT3 to examine the role of STAT3 in the pathogenesis of CRSwNP. Methods: We investigated tissue samples of the nasal polyps and inferior turbinate of patients with CRSwNP as well as samples of the inferior turbinate of subjects without chronic sinusitis. The expression levels of STAT3 and its activated form PSTAT3 were analysed using Western blotting, protein array, DNA microarray and immunohistochemistry. Results: No significant differences were found in STAT3mRNA levels between the samples of nasal polyps and inferior turbinates of the same patient. However, the amount of pSTAT3 was increased in the polyp tissue compared to the inferior turbinates from both CRSwNP patients and control subjects ( $p<0.01)$, indicating an activation of STAT3 in polyps. We identified a varying distribution pattern of pSTAT3; pSTAT3 was primarily found in superficial epithelial cells but
\end{abstract}

not in the basal layer of the epithelium of the turbinate, whereas PSTAT3 was located in all layers of the epithelium of the polyp and mostly noted in the basal layer. Conclusions: Our results of the activation and varying localisation of STAT3 and its phosphorylated form in nasal polyps suggest that PSTAT3 plays a crucial role in the proliferative development of nasal polyps.

(c) 2013 S. Karger AG, Basel

\section{Introduction}

Chronic rhinosinusitis (CRS) is one of the most common diseases in Western Europe [1] and the United States [2]. Generally, it can be distinguished between chronic rhinosinusitis with nasal polyps (CRSwNP) and chronic rhinosinusitis without nasal polyps (CRSsNP) [3, 4], but it is difficult to differentiate these two entities based on clinical impression alone [5]. CRSwNP and CRSsNP show different inflammatory patterns [6]. CRSwNP is characterised by higher eosinophilia, immunoglobulin $\mathrm{E}$ and interleukin 5 (IL-5) compared with CRSsNP. Patients with CRSwNP more often suffer from asthma than patients with CRSsNP [7]. CRSwNP is not a homogeneous disease; both eosinophilic and neutrophilic polyps occur [8]. However, in the Western World, the majority of polyps are characterised by eosinophilic infiltration [4].

\section{KARGER}

E-Mail karger@karger.com

www.karger.com/iaa
(C) 2013 S. Karger AG, Basel

1018-2438/13/1624-0290\$38.00/0
Correspondence to: Dr. Robert Linke

UK-SH, HNO-Klinik

Ratzeburger Allee 160

DE-23538 Lübeck (Germany)

E-Mail robert.linke@uk-sh.de 
The pathogenesis of nasal polyps is caused by a deranged regulation of cell growth, whereas the underlying causal molecular mechanisms and signalling pathways are not fully understood [9]. The regulation of these pathways is complex, and various phosphokinases are involved in intracellular signalling.

STAT (signal transducer and activator of transcription) proteins were discovered 20 years ago as mediators of interferon-induced gene expression. STAT proteins are involved in growth control, differentiation, apoptosis and transformation of cells, and can be activated by virtually every cytokine and growth factor [10].

STAT3, an $89-\mathrm{kDa}$ protein, is one of the 7 members of the STAT family of proteins that have been identified so far. STAT3 is a key signalling molecule: normal STAT3 signalling is tightly controlled with finite kinetics, which mediates standard cellular responses [11]. STAT3 deficiency leads to early embryonic lethality [12].

STAT3 is expressed in most tissues and is activated by a large number of different ligands [13]. The linking of these molecules to the Janus kinase (JAK) receptor leads to the phosphorylation of STAT3 at tyrosine 705 (Y705; thereafter, pSTAT3). pSTAT3 dimerises in homo- and heterodimers and migrates to the nucleus. Following phosphorylation at serine 727 (S727), pSTAT3 activates the transcription of various target genes [14].

The aberrant activation of STAT3 is observed in numerous human cancers and is widely recognised as a critical molecular abnormality and a master regulator of tumour processes [15]. Constitutively active STAT3 promotes uncontrolled growth and survival through the dysregulation of gene expression. Persistently active STAT3 induces tumour angiogenesis and modulates immune functions in favour of tumour immune evasion $[11,16]$.

STAT3 is a well-known phosphokinase involved in oncogenesis and the regulation of inflammation, and may have a function in CRSwNP. The objective of this study was to investigate the expression, activity and distribution of STAT3 in nasal polyp tissue and examine the roles of STAT3 in the pathogenesis of nasal polyps.

\section{Materials and Methods}

\section{Patients, Inclusion and Exclusion Criteria}

We examined tissue samples of nasal polyps and the inferior turbinate, as an internal control, which were harvested from 13 patients with CRSwNP during sinus surgery. Special emphasis was placed on the gentle removal of polyps without bruising or tearing. Only patients with eosinophilic CRSwNP, which was determined by histopathological examination, were included in the study to examine a subgroup of polyps that was as homogenous as possible.
No patient was treated with systemic or topical corticosteroids within 4 weeks prior to surgery. Patients with asthma and aspirin hypersensitivity were excluded to minimise overlapping effects on the phosphokinase profile of the patients.

Additionally, we examined 8 samples of the inferior turbinate of patients without any history of sinusitis or allergy who underwent septal surgery as an external control.

The study was approved by the Human Ethics Committee of the University of Luebeck (AZ_10-201) and conducted in accordance with the ethical principles for medical research formulated in the WMA Declaration of Helsinki. All patients provided signed informed consent.

\section{DNA Microarray}

Fresh tissue samples of nasal polyps and the inferior turbinate of 6 patients with CRSwNP were snap-frozen in liquid nitrogen immediately after sampling, stored at $-80^{\circ} \mathrm{C}$ and shipped on dry ice to Miltenyi Biotec (Bergisch Gladbach, Germany) for microarray analysis. The RNA was isolated and quality checked via an Agilent 2100 Bioanalyzer platform (Agilent Technologies, Santa Clara, Calif., USA), and the RNA Integrity Number was calculated. Agilent whole human genome microarrays $(4 \times 44 \mathrm{~K})$ were performed following the manufacturer's protocols. The Agilent human genome CGH microarray kit $44 \mathrm{~K}$ is a high-resolution tool for genome-wide DNA copy number variation profiling without amplification or complexity reduction. Over 43,000 coding and noncoding human sequences are represented. One glass slide is formatted with 4 high-definition $44 \mathrm{~K}$ arrays. Gene expression was calculated using the Rosetta Resolver ${ }^{\circledR}$ gene expression data analysis system (Rosetta Biosoftware, Seattle, Wash., USA).

\section{Protein Array}

The Proteome Profiler ${ }^{\mathrm{TM}}$ human phosphokinase array kit (R\&D Systems Inc., Minneapolis, Minn., USA) allows the simultaneous detection of the relative phosphorylation levels of 46 kinase phosphorylation sites. The protein array contains mitogen-activated protein kinases (MAPKs), MAPK kinases, MAPK-activated protein kinases, STATs, other transcription factors and signal transduction adaptor proteins. Capture and control antibodies are spotted in duplicate on nitrocellulose membranes.

Tissue homogenates of samples of polyps and inferior turbinates from 5 patients with CRSwNP as an internal control $(250 \mu \mathrm{g}$ of total protein/array) were applied to the phosphoprotein array following the manufacturer's instructions.

The tissue extracts were diluted and incubated overnight with the array. The array was washed to remove unbound proteins, followed by incubation with a cocktail of biotinylated detection antibodies. Streptavidin-horseradish peroxidase (HRP) and chemiluminescent detection reagents were applied, and the signal produced at each capture spot corresponded to the amount of phosphorylated protein bound.

Images were acquired using Fusion FX $7^{\circledR}$. Pixel density was analysed using the Bio-1D software ${ }^{\circledR}$ (both Vilber Lourmat, Marne-la-Vallée, France).

\section{Western Blot Analysis}

Tissue lysates of nasal polyps $(n=7)$ and inferior turbinates of patients with CRSwNP $(n=7)$, and inferior turbinates of patients with healthy mucosa $(n=8)$ were denatured by boiling for $5 \mathrm{~min}$ in $1 \times$ SDS sample buffer. The protein concentrations were deter- 
mined using the Bradford's assay, and $30 \mu \mathrm{g}$ of total protein were resolved by SDS-polyacrylamide gel electrophoresis and then transferred to nitrocellulose membranes.

The membranes were probed overnight at $4^{\circ} \mathrm{C}$ using a $1: 1,000$ dilution with the following primary antibodies in TBS-T and 5\% BSA: anti-STAT3 and anti-phospho-STAT3 (Tyr 705; No. 9131 and 9132, respectively; Cell Signaling Technology Inc., Danvers, Mass., USA). After washing, the membranes were incubated with a 1:3,333 dilution of goat anti-rabbit secondary antibody (BioRad, Hercules, Calif., USA) in TBS-T and 5\% BSA for $1 \mathrm{~h}$ at room temperature. Protein bands were visualised using an alkaline phosphatase-conjugated substrate kit (BioRad). Pixel density was quantified and documented using the Fusion FX 7 and Bio-1D software.

Nitrocellulose membranes were re-probed overnight at $4^{\circ} \mathrm{C}$ and a dilution of 1:1,000 of a primary antibody of $\beta$-actin (mAB 8226; Abcam, Cambridge, UK) to determine the loading in each lane. The membranes were washed and then incubated with a 1:1,000 dilution of species-specific HRP-linked secondary antibody in TBS-T and $5 \%$ BSA for $3 \mathrm{~h}$ at room temperature. The membranes were washed, and the protein bands were visualised as described above.

\section{Immunostaining Analysis}

Fresh-frozen tissue sections were fixed in $100 \%$ methanol for $10 \mathrm{~min}$ and then incubated with $3 \% \mathrm{H}_{2} \mathrm{O}_{2}$ in TBS for $15 \mathrm{~min}$. The sections were permeabilised with $0.3 \%$ Triton X-TBS for $15 \mathrm{~min}$ and were subsequently incubated with a 1:100 dilution of antiSTAT3 or anti-phospho-STAT3 overnight at $4^{\circ} \mathrm{C}$.

On the next day, the slides were incubated for $20 \mathrm{~min}$ at room temperature with a polylink biotinylated secondary antibody. The sections were incubated with HRP-conjugated avidin-biotin complex (both DCS Detection Line), followed by incubation with AEC (DCS Chromoline; all Innovative Diagnostik-Systeme, Hamburg, Germany). Finally, nuclear staining was performed with Mayer's haematoxylin. The sections were embedded and then viewed and photomicrographed on an Axiovert 200 inverse microscope (Carl Zeiss, Oberkochen, Germany). We defined two regions of interest (i.e. the superficial layer and the basal layer of the epithelium). The number of stained cells and the total number of cells were counted in three randomly selected non-overlapping high-power fields (HPF) per region of interest in each sample (comprising 6 total HPF in each sample). The percentage of stained cells in each HPF was determined and averaged to calculate the mean proportion of stained cells per region of interest in each sample.

\section{Statistics}

The data were normally distributed. All cases were included in the analyses. Data are presented as means and standard deviations. Microarray data were analysed using the Rosetta Resolver gene expression data analysis system. The 'Agilent/Intensity-Pairwise Ratio Builder' pipeline from the Rosetta software was used for data normalisation and to build ratio experiments. Within this pipeline, the 'Build Pairwise Ratios' step applies the 'Agilent Single Colour Ratio Error Model' to the profiles and builds the ratios. The applied normalisation was based on the Rosetta Affymetrix error model [17]. The indicated $\mathrm{p}$ value was calculated from X Dev, which considers both the $\log$ (ratio) and $\log$ (error).

The data were analysed with one- and two-way ANOVA, followed by Fisher's exact test, using the Stat View 5.0 software (SAS Institute, Cary, N.C., USA). Values of $\mathrm{p}<0.05$ were considered statistically significant.

\section{Results}

\section{Clinical Data of the Patients}

All patients had a history of sinus-related complaints for more than 3 months with a mean duration of 1.3 years ( \pm 0.8 years), and conservative therapy had failed. The Lund-Mackay scoring system (0-24) was used to grade the radiographic occupancy of sinus disease [18]. All patients suffered from bilateral polyposis; the mean LundMackay score of the patients was $17.3( \pm 4.2)$. Endoscopic findings were classified according to the Lund-Kennedy scoring system (0-14) [19]; the mean score was 10.7 $( \pm 1.7)$. Quality of life was evaluated by the Sino-Nasal Outcome Test-20 German Adapted Version [20,21] and gave a value of $34.4( \pm 13.6)$. The clinical and demographic characteristics of all patients included in the study are reported in table 1.

\section{Increased Activity of STAT3 in Nasal Polyps}

The evaluation of the DNA microarray (NM_213662) showed no quantitative difference in the amount of STAT3-mRNA between the samples of nasal polyps and the inferior turbinates from the same patient $(n=6)$; the mean fold change was 0.99 (SD 0.23; fig. 1).

Western blot analysis showed no differences in the expression of unphosphorylated STAT3 in the polyps (0.87; SD $0.23 ; \mathrm{n}=7)$ and turbinates of patients with CRSwNP $(0.89 ; \mathrm{SD} 0.24 ; \mathrm{n}=7)$ compared with healthy mucosa $(1.00 ; \mathrm{SD} 0.33 ; \mathrm{n}=8)$. We detected a 1.72 -fold increase in pSTAT3 in the nasal polyps $(n=7)$ compared with the inferior turbinates of patients with CRSwNP $(\mathrm{n}=7, \mathrm{p}<$ 0.01 ) and a 2.12-fold increase compared with healthy mu$\operatorname{cosa}(\mathrm{n}=8, \mathrm{p}<0.01)$. We observed no significant difference between the turbinates of patients with CRSwNP and healthy mucosa (fig. 2).

Quantitative analysis of the protein array showed a significantly increased level of PSTAT3 in the polyp tissue in each pair of the polyp and turbinate samples from the same patient with CRSwNP. The mean concentration of pSTAT3 in the polyps was 2.08 -fold higher than that observed in the inferior turbinates $(n=5, p<0.01$; fig. 3$)$.

\section{Altered Localisation of STAT3 in Nasal Polyps}

Haematoxylin and eosin staining of the nasal turbinates of patients with both healthy mucosa and CRSwNP showed the typical multi-row ciliated epithelium, with goblet cells included. Variable degrees of hyperplasia and focal squamous metaplasia were found in the epithelium of the nasal polyps. Data from the histopathological examination of the polyps are listed in table 2 . 
Table 1. Clinical and demographic characteristics of the patients

\begin{tabular}{|c|c|c|c|c|c|c|c|}
\hline 1 & male & 52 & 21 & 11 & 12 & 20 & M \\
\hline 2 & female & 39 & 12 & 8 & 12 & 0 & $\mathrm{M}$ \\
\hline 3 & male & 41 & 19 & 12 & 7 & 7 & M \\
\hline 4 & male & 58 & 22 & 11 & 14 & 0 & $\mathrm{M}$ \\
\hline 7 & female & 54 & 12 & 8 & 12 & 25 & $\mathrm{P}, \mathrm{WB}, \mathrm{IHC}-\mathrm{F}$ \\
\hline 8 & male & 47 & 21 & 11 & 12 & 40 & $\mathrm{P}, \mathrm{WB}, \mathrm{IHC}-\mathrm{F}$ \\
\hline 9 & male & 81 & 24 & 12 & 42 & 0 & $\mathrm{P}, \mathrm{WB}, \mathrm{IHC}-\mathrm{F}$ \\
\hline 10 & female & 44 & 16 & 8 & 11 & 0 & $\mathrm{P}, \mathrm{WB}, \mathrm{IHC}-\mathrm{F}$ \\
\hline 11 & male & 31 & 11 & 8 & 18 & 0 & WB, IHC-F \\
\hline 12 & male & 47 & 18 & 12 & 9 & 15 & WB, IHC-F \\
\hline
\end{tabular}

$\mathrm{M}=$ DNA microarray; $\mathrm{P}=$ protein array; $\mathrm{WB}=$ western blot; $\mathrm{IHC}-\mathrm{F}=$ immunohistochemistry (frozen).

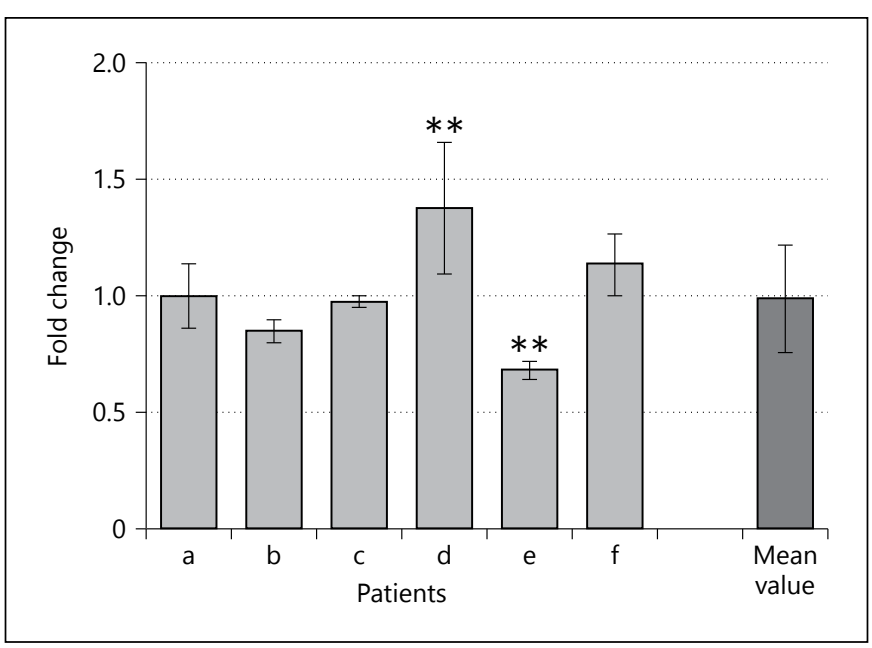

Fig. 1. DNA microarray results (NM_213662). Fold change of STAT3-mRNA between the polyps and inferior turbinates from the same patient with CRSwNP and the mean $( \pm \mathrm{SD})$ fold change. ** $\mathrm{p}<0.01$.

Immunohistochemically, STAT3 staining was particularly present in the outer cell layer of the epithelium of both the nasal turbinate of patients with CRSwNP and the healthy mucosa (fig. 4a, b). STAT3 was uniformly expressed in the cytoplasm of epithelial cells in all layers of nasal polyp tissue (fig. 4c). The percentage of stained cells in the basal layer of the epithelium was significantly different between the polyps $(n=6)$ and the turbinates of patients with CRSwNP $(\mathrm{n}=6$; $\mathrm{p}<0.05)$ and healthy mu$\operatorname{cosa}(\mathrm{n}=6 ; \mathrm{p}<0.05)$.

The different distribution of pSTAT3 in polyp tissue was even more striking. pSTAT3 was evident in only a few nuclei in the epithelium of the turbinates of patients with healthy mucosa (fig. 4d). In the turbinates of patients with CRSwNP, pSTAT3 was found in the nuclei of almost all cells in the superficial cell layer and sporadically in the basal layer (fig. 4e).

However, pSTAT3 was observed in both the superficial and basal layer of the epithelium of the polyps. The difference between the percentage of stained cells in the basal layer of the epithelium between the polyps $(n=6)$ and both the turbinates of patients with CRSwNP $(n=6$; $\mathrm{p}<0.001)$ and the healthy mucosa $(\mathrm{n}=6 ; \mathrm{p}<0.01)$ is highly significant (fig. 4f).

A semiquantitative analysis of the distribution pattern of immunohistochemical staining is listed in table 3.

\section{Discussion}

The etiopathogenesis of CRS and especially of nasal polyps still needs to be clarified. Epithelial damage, aberrant tissue remodelling and hyperplasia are typical features of CRSwNP. Cellular growth seems to be dysregulated in polyps. A greater proportion of proliferating cells and increased apoptosis have been identified in the epithelial cells of polyps compared with normal mucosa [22]. 
Fig. 2. Representative example of Western blotting. a STAT3 and pSTAT3 in polyps $(\mathrm{p})$, turbinates $(\mathrm{t})$ and healthy mucosa $(\mathrm{h})$. Re-probing with an antibody against $\beta$-actin demonstrates equal protein loading in each lane. $\mathbf{b}$ Mean levels $( \pm S D)$ of STAT3 and PSTAT3 in polyps and inferior turbinates of patients with CRSwNP compared with healthy mucosa. ${ }^{* *} \mathrm{p}<0.01$.

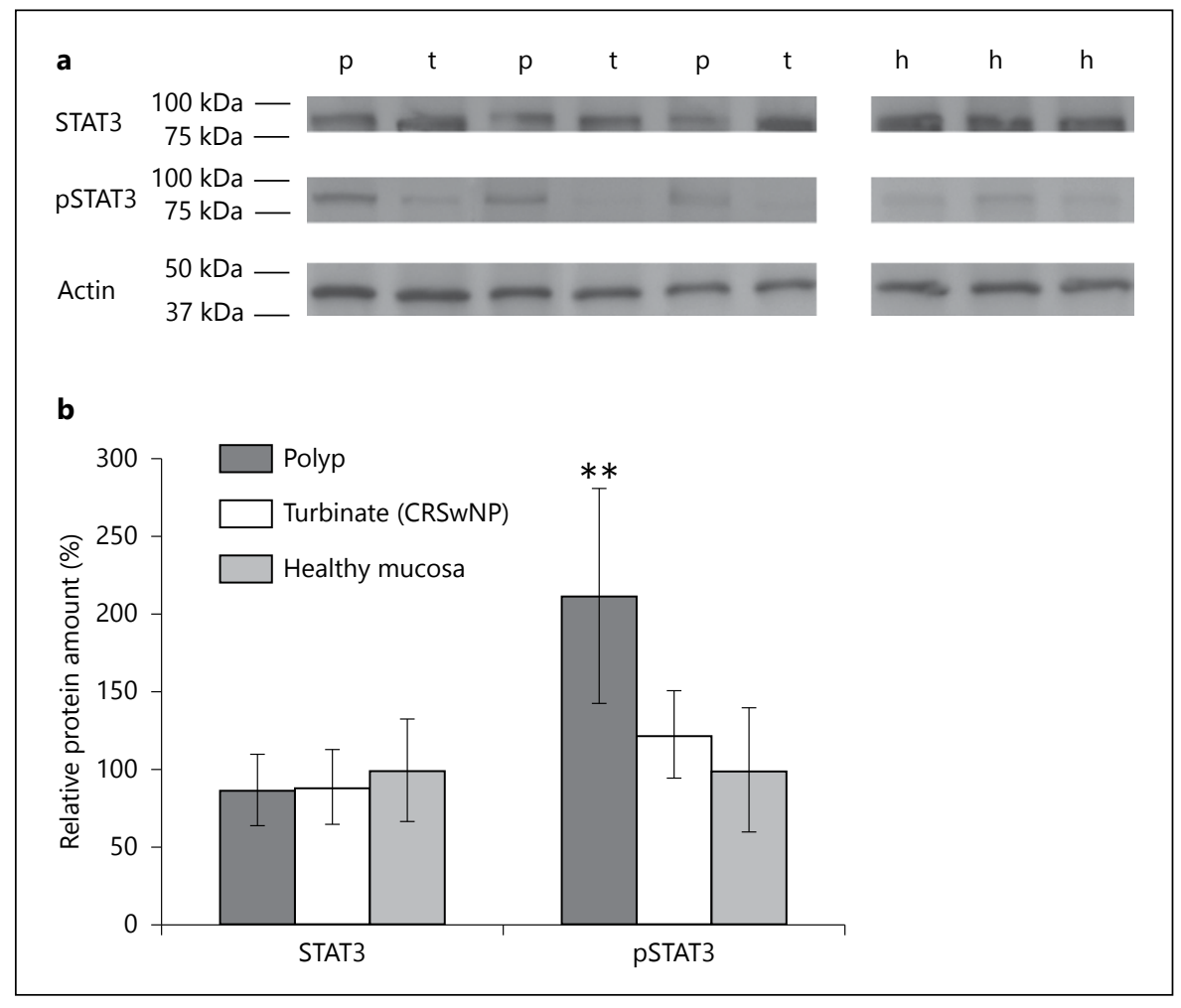

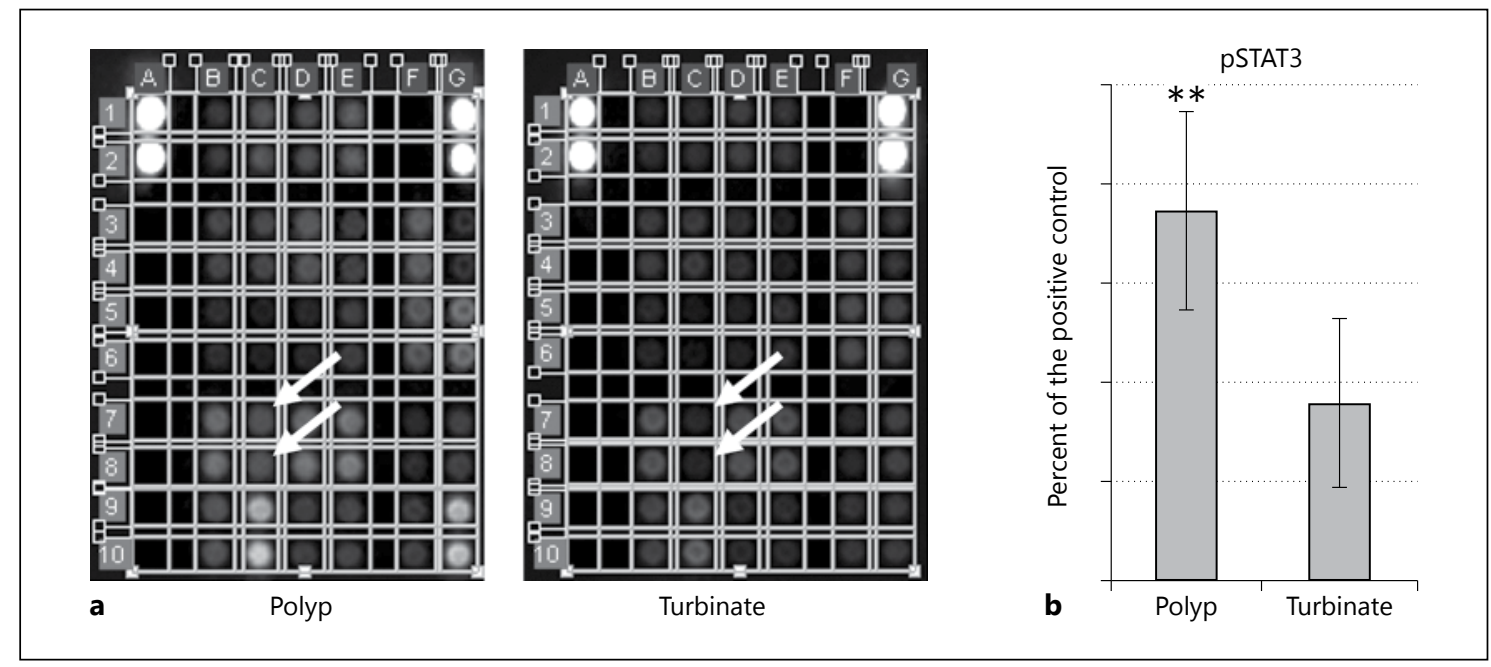

Fig. 3. Protein array results. a Example of a representative protein array of a polyp and an inferior turbinate from the same patient. The spot for pSTAT3 on the membrane is marked. $\mathbf{b}$ Mean levels $( \pm \mathrm{SD})$ of $\mathrm{pSTAT3}{ }^{* *} \mathrm{p}<0.01$.

The contribution of signalling pathways that regulate the growth of nasal polyps remains poorly defined. The activation or inactivation of the enzymes involved in these pathways is often carried out by various phosphokinases, such as STAT3.
So far, only two studies exist on the role of STAT3 and pSTAT3 in the development of nasal polyps and they have contradictory results. Peters et al. [23] measured the concentration of STAT3 and pSTAT3 by Western blot in tissue samples of nasal polyps and inferior turbinates of 

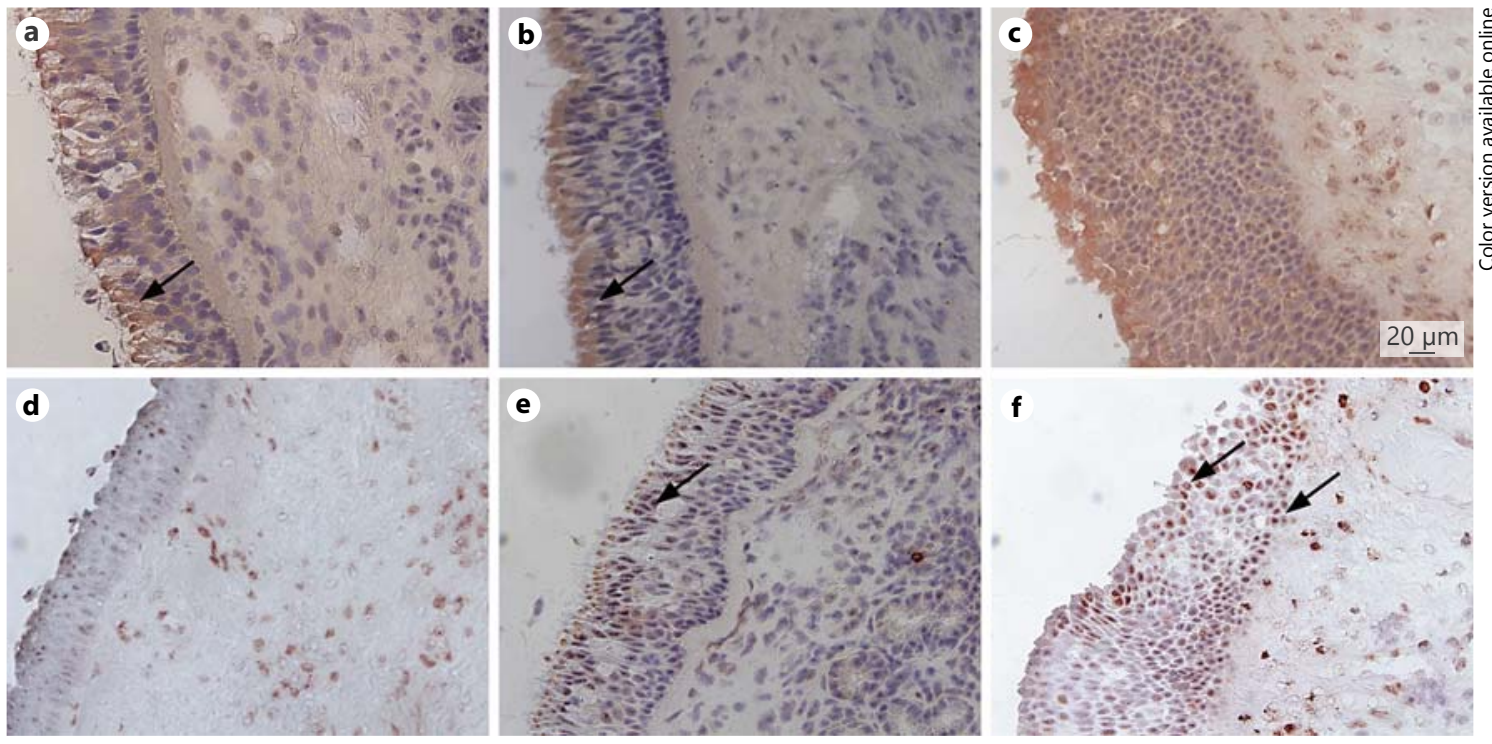

Fig. 4. Representative examples of immunostaining with haematoxylin counterstaining. STAT3 is located mainly in the superficial layer (arrow) of the epithelium of both the inferior turbinate of healthy mucosa (a) and the inferior turbinate of a patient with CRSwNP (b). In polyps, a uniform cytoplasmic expression of STAT3 was found in all layers of the epithelium (c).
The cells of the epithelium in healthy mucosa hardly express pSTAT3 (d). pSTAT3 is expressed in almost all nuclei of the superficial epithelial layer (arrow) of the inferior turbinate of a patient with CRSwNP (e). pSTAT3 is expressed in the superficial layer and in the proliferating basal epithelial layer (arrows) of a nasal polyp (f).
Table 2. Histopathological examination of the polyps

\begin{tabular}{lcc}
\hline Histologic measures & Mean \pm SD & $\%$ \\
\hline Cellular markers, absolute n/HPF & & \\
$\quad$ Eosinophils & $50.1 \pm 26.3$ & \\
Neutrophils & $3.5 \pm 1.7$ & \\
Lymphocytes & $27.2 \pm 8.2$ & \\
Plasma cells & $27.0 \pm 6.9$ & \\
Macrophages & $15.0 \pm 6.6$ & \\
Mast cells & $6.3 \pm 2.9$ & \\
Epithelial markers & & \\
Goblet cells, \% & $7.0 \pm 1.8$ & \\
$\quad$ Thickness of the basal membrane, $\mu \mathrm{m}$ & $7.5 \pm 3.1$ & \\
$\quad$ Epithelial hyperplasia & & 33 \\
$\quad$ Squamous metaplasia & & 100 \\
Stromal markers & & 17 \\
$\quad$ Subepithelial oedema & & \\
$\quad$ Mucosal fibrosis & & \\
\hline
\end{tabular}

patients with CRSwNP and performed immunohistochemistry in tissue samples of the nasal polyps and uncinates of patients with CRSwNP. They found lower levels of pSTAT3 in the tissue samples from polyps compared to controls. The group of Cao and Zhang performed immunohistochemistry in tissue samples of the nasal polyps and inferior turbinates of patients who underwent septal
Table 3. Semiquantitative analysis of immunohistological staining of STAT3 and pSTAT3 in the epithelium $(n=6)$

\begin{tabular}{lcc}
\hline Localization & STAT3 & pSTAT3 \\
\hline Superficial layer & & \\
$\quad$ Healthy mucosa (control) & $16.7(10.4)$ & $10.0(6.1)$ \\
$\quad$ Turbinate (CRSwNP) & $50.7(15.9)$ & $58.7(20.0)$ \\
$\quad$ Polyp & $47.5(23.1)$ & $58.3(21.4)$ \\
Basal layer & & \\
$\quad$ Healthy mucosa (control) & $2.8(1.3)$ & $17.5(4.8)$ \\
$\quad$ Turbinate (CRSwNP) & $4.3(1.6)$ & $6.7(2.6)$ \\
Polyp & $43.8(22.1)$ & $54.3(16.5)$ \\
\end{tabular}

Mean percentages of stained cells (SD) are shown.

surgery as controls. The positive rate of STAT3 and pSTAT3 was significantly higher in nasal polyps than in controls $[24,25]$.

We examined tissue samples of polyps from a welldefined subpopulation of patients with eosinophilic bilateral CRSwNP and two different types of controls with a battery of four tests. We did not find a difference in the amount of mRNA between polyps and inferior turbinates of patients with CRSwNP or healthy mucosa. Furthermore, no difference could be detected in the concentra- 
tion of non-phosphorylated STAT3 protein between polyps and inferior nasal turbinate of patients with CRSwNP or healthy mucosa. However, pSTAT3 concentration was increased in nasal polyps compared with inferior turbinates of patients with CRSwNP and healthy mucosa, suggesting that this critical point of the STAT3 cascade is altered. We conclude that in CRSwNP the regulation of STAT3 is disrupted exclusively at the phosphorylation level.

In agreement with the group of Cao and Zhang, we observed a higher amount of pSTAT3 in nasal polyps compared to controls [24, 25], but we did not observe a higher expression of STAT3. In contrast to our study, Peters et al. [23] included patients who were treated with corticosteroids. Because corticosteroids are effective in the conservative treatment of CRSwNP [4], they most likely change the phosphokinase profile of the tissue. Furthermore, Peters et al. [23] studied mucosa of the uncinate of patients with CRSwNP (tissue of the middle meatus) as a control in their immunohistochemistry analysis. We used the mucosa of the inferior meatus, where polyps never occur. The differing results of the three studies could be explained by the different patient selection criteria and different types of controls.

Although no major histological difference was found in the nasal mucosa and polyps obtained from African, Chinese and Caucasian patients [26], different inflammatory patterns have been discussed in patients of different races $[4,27-30]$. The different origin of the patients is another possible explanation of the diverse results. Other possible confounders, including biofilms [31] and infection/colonisation with fungi [32] or Staphylococcus aureus [33], were not examined in our study or in the studies of the other research groups because these aspects were beyond the scope of the studies.

This work differs from many purely molecular biological studies in that we have measured not only the amount of protein but also its spatial distribution. The real surprise in our results was the different distribution of pSTAT3 in the cells of the epithelium of polyps and inferior turbinates, which had not been reported previously. In the 1990s, a rupture of the basal membrane, which was followed by interstitial oedema, was suspected as the cause of polyp formation based on light-microscopic findings in a rat model $[34,35]$. Our studies provide clear indications, obtained using an immunohistochemical method, that the STAT3 pathway is turned on, which is known in oncology, and that the phosphorylation rate of a key signalling molecule is up-regulated in the basal cell layer of the pathologically altered epithelium of nasal polyps.
The distribution of STAT3 and pSTAT3 in the turbinates of patients with CRSwNP and healthy mucosa is very similar. Our findings provide a possible explanation as to why nasal polyps rarely occur in the region of the inferior turbinate.

Distinct and partially contradictory roles of STAT3 in the immune system have been described. Although antiinflammatory effects have been reported [36], STAT3 has been considered an activator of the expression of proinflammatory genes $[37,38]$ and may play a critical role in the control of mucosal immune tolerance [39].

STAT3 is a key element of the downstream signalling of IL-6 [40]. Increased amounts of IL-6 were reported in patients with CRSwNP [23, 41]. IL-17 has been found in the upper respiratory tract, and it stimulates the survival and degranulation of eosinophils [42]. An enhanced Th17 response in nasal polyps has also been demonstrated [43, 44, 45], regardless of eosinophilic or non-eosinophilic inflammation [43]. An impaired balance of Th17 and regulatory $\mathrm{T}$ cells was reported in patients with CRSwNP [46], as Th17 airway inflammation is enhanced by an IL-6- and IL-17-positive feedback loop [47, 48]. Our findings provide evidence that STAT3, an element of the downstream signalling of both IL-6 and IL-17, is activated in nasal polyps.

As early as 1863, Rudolf Virchow hypothesised that micro-inflammation resulting from irritation leads to enhanced cell proliferation $[49,50]$. STAT3 regulates the expression of target genes involved in cell-cycle progression and apoptosis and promotes cellular transformation as well as abnormal cell proliferation. STAT3 is considered a suppressor of apoptosis [51-53]. It is commonly discussed as a link between inflammation and cancer [54].

CRSwNP is a recurrent, benign and extremely proliferative disease that is triggered by inflammation. STAT3, which is activated in nasal polyps and localised in epithelial cells facing the basal membrane, may drive the development of nasal polyps by inhibiting apoptosis in the epithelium, which is otherwise induced by a chronic inflammatory condition.

Curcumin (diferuloylmethane) is a naturally occurring compound found in the plant Curcuma longa that has numerous medicinal properties, including anti-inflammatory and anti-tumor effects [55]. Several small molecule STAT3 inhibitors have been developed by modifying curcumin, and some have shown promising activity both in vitro and in mouse xenograft models [5658]. Agents with biologic activity inhibiting STAT3-related cellular functions may have therapeutic potential in the treatment of malignant tumours [59] and possibly
Linke/Pries/Könnecke/Bruchhage/ Böscke/Gebhard/Wollenberg 
CRSwNP. Future work with STAT3 inhibitors has to define the therapeutic potential of these agents in CRSwNP in vitro and, maybe later, in vivo in more detail.

The JAK-STAT pathway is one pathway among many others that directs the proliferation, differentiation and apoptosis of cells. Evaluating the expression of regulatory proteins that direct the cells throughout their cycle in nasal polyps may allow a better understanding of the biological behaviour of polyps and may improve the clinical outcome of therapy for these benign pathological entities.

\section{Acknowledgements}

We are grateful to Brigitte Wollman and Birgit Hüsing for their skilful support in several parts of this work and to all of the members of the Department of Otorhinolaryngology for helpful discussions and a comfortable atmosphere. There are no conflicts of interest. This work was supported by Klosterfrau GmbH, Köln, Germany.

\section{References}

1 Hastan D, Fokkens WJ, Bachert C, Newson RB, Bislimovska J, Bockelbrink A, Bousquet PJ, Brozek G, Bruno A, Dahlén SE, Forsberg B, Gunnbjörnsdóttir M, Kasper L, Krämer U, Kowalski ML, Lange B, Lundbäck B, Salagean E, Todo-Bom A, Tomassen P, Toskala E, van Drunen CM, Bousquet J, Zuberbier T, Jarvis D, Burney P: Chronic rhinosinusitis in Europe - an underestimated disease. A GA(2) LEN study. Allergy 2011;66:1216-1223.

$>2$ Pleis JR, Lucas JW, Ward BW: Summary health statistics for US adults: National Health Interview Survey, 2008. Vital Health Stat 2009;10:1-157.

-3 Van Crombruggen K, Van Bruaene N, Holtappels G, Bachert C: Chronic sinusitis and rhinitis: clinical terminology 'Chronic Rhinosinusitis' further supported. Rhinology 2010;48:54-58.

-4 Fokkens WJ, Lund VJ, Mullol J, Bachert C, Alobid I, Baroody F, Cohen N, Cervin A, Douglas R, Gevaert P, Georgalas C, Goossens H, Harvey R, Hellings P, Hopkins C, Jones N, Joos G, Kalogjera L, Kern B, Kowalski M, Price D, Riechelmann H, Schlosser R, Senior B, Thomas M, Toskala E, Voegels R, Wang de Y, Wormald PJ: European Position Paper on Rhinosinusitis and Nasal Polyps 2012. Rhinol Suppl 2012:3 p preceding table of contents, 1-298.

$\checkmark 5$ Dietz de Loos DA, Hopkins C, Fokkens WJ: Symptoms in chronic rhinosinusitis with and without nasal polyps. Laryngoscope 2013; 123:57-63.

-6 Zhang N, Holtappels G, Claeys C, Huang G, van Cauwenberge $P$, Bachert C: Pattern of inflammation and impact of Staphylococcus aureus enterotoxins in nasal polyps from southern China. Am J Rhinol 2006;20:445-450.

7 Johansson L, Akerlund A, Holmberg K, Melen I, Bende M: Prevalence of nasal polyps in adults: the Skovde population-based study. Ann Otol Rhinol Laryngol 2003;112:625-629.

$>8$ Onerci M, Elsurer C, Guzel E, Dagdeviren A: Distribution of inflammatory cells, adhesion molecules, intermediate filaments, and chemokine receptors in subgroups of nasal polyp patients. Am J Rhinol Allergy 2011;27:e176e180.

\section{$\checkmark 9$ Fruth K, Schramek E, Docter D, Haxel BR, Schneider A, Mann WJ, Brieger J: Dysregu- lated survivin expression in nasal polyps of individuals with aspirin exacerbated respira- tory disease. Am J Rhinol Allergy 2012;26: 380-384.}

$>10$ Bromberg JF: Activation of STAT proteins and growth control. Bioessays 2001;23:161169.

$>11$ Turkson J: STAT proteins as novel targets for cancer drug discovery. Expert Opin Ther Targets 2004;8:409-422.

12 Takeda K, Noguchi K, Shi W, Tanaka T, Matsumoto M, Yoshida N, Kishimoto T, Akira S: Targeted disruption of the mouse Stat 3 gene leads to early embryonic lethality. Proc Natl Acad Sci USA 1997;94:3801-3804.

13 Bromberg JF, Darnell JE Jr: The role of STATs in transcriptional control and their impact on cellular function. Oncogene 2000;19:24682473.

14 Darnell JE Jr, Kerr IM, Stark GR: Jak-STAT pathways and transcriptional activation in response to IFNs and other extracellular signaling proteins. Science 1994;264:14151421.

15 Page BD, Ball DP, Gunning PT: Signal transducer and activator of transcription 3 inhibitors: a patent review. Expert Opin Ther Pat 2011;21:65-83.

16 Kujawski M, Kortylewski M, Lee H, Herrmann A, Kay H, Yu H: Stat3 mediates myeloid cell-dependent tumor angiogenesis in mice. J Clin Invest 2008;118:3367-3377.

17 Weng L, Dai H, Zhan Y, He Y, Stepaniants SB, Bassett DE: Rosetta error model for gene expression analysis. Bioinformatics 2006;22: 1111-1121.

18 Lund VJ, Mackay IS: Staging in rhinosinusitus. Rhinology 1993;31:183-184.

19 Lund VJ, Kennedy DW: Staging for rhinosinusitis. Otolaryngol Head Neck Surg 1997; 117:35-40.

20 Baumann I, Plinkert PK, De Maddalena H: Development of a grading scale for the SinoNasal Outcome Test-20 German Adapted Version (SNOT-20 GAV). HNO 2008;56: 784-788.
21 Piccirillo JF, Merritt MG Jr, Richards ML: Psychometric and clinimetric validity of the 20-Item Sino-Nasal Outcome Test (SNOT20). Otolaryngol Head Neck Surg 2002;126: 41-47.

22 Garavello W, Viganò P, Romagnoli M, Sordo L, Berti E, Tredici G, Gaini RM: Expression of cell cycle regulatory proteins and analysis of apoptosis in normal nasal mucosa and in nasal polyps. Am J Rhinol 2005;19:549-553.

23 Peters AT, Kato A, Zhang N, Conley DB, Suh L, Tancowny B, Carter D, Carr T, Radtke M, Hulse KE, Seshadri S, Chandra R, Grammer LC, Harris KE, Kern R, Schleimer RP: Evidence for altered activity of the IL- 6 pathway in chronic rhinosinusitis with nasal polyps. J Allergy Clin Immunol 2010;125:397-403.

24 Zhang T, Cao Q, Wang L, Luo S, Tu Z: Expression and correlation of STAT3 with VEGF in the nasal polyps. Chin J Pathophysiol 2009;25: 993-997.

25 Cao Q, Zhang T, Jiang L, Wang L, Luo S: Expression and significance of STAT3 and VEGF with MVD in the nasal polyps (in Chinese). Lin Chung Er Bi Yan Hou Tou Jing Wai Ke Za Zhi 2010;24:641-644, 647.

-26 Lacroix JS, Zheng CG, Goytom SH, Landis B, Szalay-Quinodoz I, Malis DD: Histological comparison of nasal polyposis in black African, Chinese and Caucasian patients. Rhinology 2002;40:118-121.

27 Cao PP, Li HB, Wang BF, Wang SB, You XJ, Cui YH, Wang DY, Desrosiers M, Liu Z: Distinct immunopathologic characteristics of various types of chronic rhinosinusitis in adult Chinese. J Allergy Clin Immunol 2009; 124:478-484.

28 Zhang N, Liu S, Lin P, Li X, van Bruaene N, Zhang J, van Zele T, Bachert C: Remodeling and inflammation in Chinese versus white patients with chronic rhinosinusitis. J Allergy Clin Immunol 2010;125:507, author reply 507-508.

29 Jiang XD, Li GY, Li L, Dong Z, Zhu DD: The characterization of IL-17A expression in patients with chronic rhinosinusitis with nasal polyps. Am J Rhinol Allergy 2011;25:e171e175. 
30 Nakayama T, Yoshikawa M, Asaka D, Okushi T, Matsuwaki Y, Otori N, Hama T, Moriyama $\mathrm{H}$ : Mucosal eosinophilia and recurrence of nasal polyps - new classification of chronic rhinosinusitis. Rhinology 2011;49:392-396.

-31 Tóth L, Vajas A, Csomor P, Berta A, Sziklai I, Karosi T: Optical coherence tomography for biofilm detection in chronic rhinosinusitis with nasal polyposis. Eur Arch Otorhinolaryngol 2013;270:555-563.

- 32 Ponikau JU, Sherris DA, Kephart GM, Adolphson C, Kita $\mathrm{H}$ : The role of ubiquitous airborne fungi in chronic rhinosinusitis. Clin Rev Allergy Immunol 2006;30:187-194.

-33 Bachert C, Zhang N, Patou J, van Zele T, Gevaert $P$ : Role of staphylococcal superantigens in upper airway disease. Curr Opin Allergy Clin Immunol 2008;8:34-38.

34 Larsen PL, Tos M: Polyp formation by experimental tubal occlusion in the rat. Acta Otolaryngol 1991;111:926-933.

- 35 Larsen PL, Tos M, Kuijpers W, van der Beek JM: The early stages of polyp formation. Laryngoscope 1992;102:670-677.

36 Egwuagu CE: STAT3 in CD4+ T helper cell differentiation and inflammatory diseases. Cytokine 2009;47:149-156.

- 37 Darnell JE: Validating Stat3 in cancer therapy. Nat Med 2005;11:595-596.

- 38 Yu H, Pardoll D, Jove R: STATs in cancer inflammation and immunity: a leading role for STAT3. Nat Rev Cancer 2009;9:798-809.

- 39 Welte T, Zhang SS, Wang T, Zhang Z, Hesslein DG, Yin Z, Kano A, Iwamoto Y, Li E, Craft JE, Bothwell AL, Fikrig E, Koni PA, Flavell RA, Fu XY: STAT3 deletion during hematopoiesis causes Crohn's disease-like pathogenesis and lethality: a critical role of STAT3 in innate immunity. Proc Natl Acad Sci USA 2003;100:1879-1884.

40 Mitsuyama K, Matsumoto S, Masuda J, Yamasakii H, Kuwaki K, Takedatsu H, Sata M: Therapeutic strategies for targeting the IL-6/ STAT3 cytokine signaling pathway in inflammatory bowel disease. Anticancer Res 2007; 27:3749-3756.

41 Sachse F, Becker K, von Eiff C, Metze D, Rudack C: Staphylococcus aureus invades the epithelium in nasal polyposis and induces IL-6 in nasal epithelial cells in vitro. Allergy 2010;65:1430-1437.
42 Bystrom J, Patel SY, Amin K, Bishop-Bailey D: Dissecting the role of eosinophil cationic protein in upper airway disease. Curr Opin Allergy Clin Immunol 2012;12:18-23.

43 Jiang XD, Li GY, Li L, Dong Z, Zhu DD: The characterization of IL-17A expression in patients with chronic rhinosinusitis with nasal polyps. Am J Rhinol Allergy. 2011;25:e171e175.

44 Shen Y, Pan CK, Tang XY, Yang YC, Ke X, Kou W, Wang XQ, Hong SL: Significance of interleukin-17A in patients with nasal polyposis. Asian Pac J Allergy Immunol 2011;29: 169-175.

45 Molet SM, Hamid QA, Hamilos DL: IL-11 and IL-17 expression in nasal polyps: relationship to collagen deposition and suppression by intranasal fluticasone propionate. Laryngoscope 2003;113:1803-1812.

46 Shen Y, Tang XY, Yang YC, Ke X, Kou W, Pan CK, Hong SL: Impaired balance of Th17/Treg in patients with nasal polyposis. Scand J Immunol 2011;74:176-185.

-47 Camporeale A, Poli V:IL-6, IL-17 and STAT3: a holy trinity in auto-immunity? Front Biosci 2012;17:2306-2326.

48 Moon HG, Kang CS, Choi JP, Choi DS, Choi HI, Choi YW, Jeon SG, Yoo JY, Jang MH, Gho YS, Kim YK: Acetyl salicylic acid inhibits Th17 airway inflammation via blockade of IL-6 and IL-17 positive feedback. Exp Mol Med 2013;45:e6.

49 Virchow R: Die krankhaften Geschwülste: 30 Vorlesungen, geh. während d. Wintersemesters 1862-1863 an d. Univ. zu Berlin. Stumen, Myome, Neurome, Angiome, ed 1. Berlin, Hirschwald, 1865, vol 2, pp 106-169.

50 Demaria M, Poli V: Pro-malignant properties of STAT3 during chronic inflammation. Oncotarget 2012;3:359-360.

51 Niu G, Wright KL, Ma Y, Wright GM, Huang M, Irby R, Briggs J, Karras J, Cress WD, Pardoll D, Jove R, Chen J, Yu H: Role of Stat3 in regulating p53 expression and function. Mol Cell Biol 2005;25:7432-7440.
52 Niu G, Shain KH, Huang M, Ravi R, Bedi A, Dalton WS, Jove R, Yu H: Overexpression of a dominant-negative signal transducer and activator of transcription 3 variant in tumor cells leads to production of soluble factors that induce apoptosis and cell cycle arrest. Cancer Res 2001;61:3276-3280.

53 Zhang Q, Wang HY, Marzec M, Raghunath PN, Nagasawa T, Wasik MA: STAT3- and DNA methyltransferase 1-mediated epigenetic silencing of SHP-1 tyrosine phosphatase tumor suppressor gene in malignant $\mathrm{T}$ lymphocytes. Proc Natl Acad Sci USA 2005;102: 6948-6953.

54 Aggarwal BB, Kunnumakkara AB, Harikumar KB, Gupta SR, Tharakan ST, Koca C, Dey S, Sung B: Signal transducer and activator of transcription-3, inflammation, and cancer: how intimate is the relationship? Ann NY Acad Sci 2009;1171:59-76.

55 Gota VS, Maru GB, Soni TG, Gandhi TR, Kochar N, Agarwal MG: Safety and pharmacokinetics of a solid lipid curcumin particle formulation in osteosarcoma patients and healthy volunteers. J Agric Food Chem 2010;58:20952099.

56 Fossey SL, Bear MD, Lin J, Li C, Schwartz EB, Li PK, Fuchs JR, Fenger J, Kisseberth WC, London CA: The novel curcumin analog FLLL32 decreases STAT3 DNA binding activity and expression, and induces apoptosis in osteosarcoma cell lines. BMC Cancer 2011;11:112.

57 Lin L, Hutzen B, Li PK, Ball S, Zuo M, DeAngelis $\mathrm{S}$, Foust E, Sobo M, Friedman L, Bhasin D, Cen L, Li C, Lin J: A novel small molecule, LLL12, inhibits STAT3 phosphorylation and activities and exhibits potent growth-suppressive activity in human cancer cells. Neoplasia 2010;12:39-50.

58 Onimoe GI, Liu A, Lin L, Wei CC, Schwartz EB, Bhasin D, Li C, Fuchs JR, Li PK, Houghton P, Termuhlen A, Gross T, Lin J: Small molecules, LLL12 and FLLL32, inhibit STAT3 and exhibit potent growth suppressive activity in osteosarcoma cells and tumor growth in mice. Invest New Drugs 2012;30:916-926.

-59 Couto JI, Bear MD, Lin J, Pennel M, Kulp SK, Kisseberth WC, London CA: Biologic activity of the novel small molecule STAT3 inhibitor LLL12 against canine osteosarcoma cell lines. BMC Vet Res 2012;8:244. 